\title{
MINI GROUP DISCUSSION: \\ COOPERATIVE LEARNING IN TEACHING READING
}

\author{
a Maskhurin Fajarina, bSayid Ma'rifatullah \\ UNHASY Tebuireng Jombang \\ e-mail: Emfajarina@gmai.com
}

\begin{abstract}
The aim of the research is to determine mini-group discussion as a cooperative learning in teaching reading. In the article, the method used is quantitative and descriptive qualitative which focus on teaching reading English text of Unhasy Students nonEnglish department. It focus on some problems, those are How the implementation of mini group discussion (mindis) in teaching reading English and How the influence of (Mindis) into students' enhancement in reading English comprehension. The researcher used test as an instrument and interview of the students. The result of the research are Mindis is easy to teach reading English in non-English department and it has significant influence into the students' enhancement in reading English.
\end{abstract}

Keywords: mindis, teaching reading, students' enhancement 


\section{INTRODUCTION}

English in not a new language anymore, it is very famous then many people use the language into their daily, even they switch the language or sometimes mix the language, sometimes in correct or incorrect pronunciation. But those prove that English is become common. Even though English famous and common for many people, not all people understand English moreover academic English text. Usually they who study academically in formal studies; junior high school, senior high school, and university, they have academic English text, that is not English what common people use. Those, what people think that English is difficult than English is still as a foreign language which we need to learn, understand, practice in.

English has four skills that need to be mastered according to your needs. In general, language skills are interrelated; speaking skills, listening skills, reading skills, and writing skills. Related to the academic field, language is a tool to access, store and distribute information, English does too. For a non-English department, language competence is that they are able to understand simple texts related to their fields and the simple communication language they often use.

Factually, English can be accepted by the general public through games, songs, movies, etc. However, many students have difficulty in understanding English moreover in understanding English text. They think English is difficult to understand because they have to memorize a lot of vocabularies, learning English must memorize many formulas of sentences, English may not be pronounced based on writing, and sometimes English becomes a scary thing because the teacher and the methods used are not able to support it properly. In a large class conditions, the students cannot receive the material well and the teacher feel same. So that students feel that English is a difficult and boring thing.

Based on the explanation above, the researcher is going to concern on some problems; 1)how is the implementation of Mini Group Discussion to the students of Economic Syari'ah low Unhasy (Hukum Ekonomi syariah Unhasy)?How is the influence of Mini Group Discussion into students' understanding to the English text. By the result of the research, the implementation of mindis is known in teaching English to the students of HES and the influence to the students understanding into English text.

\section{Review of Related Literature}

\section{Reading Comprehension}

Reading is one of the language skills which is important not only for the English department students but also many students need to be able to read to get wide knowledge. Reading comprehension is one kind of reading. It can be pronounced or not. Reading comprehension involves taking knowledge to a text in order to catch the meaning from the text. It is a process in which the reader has to decipher language and construct a meaningful whole as intended by the writer. Wainwright (2007:38) gave addition that reading comprehension is not only reading aloud and out loud pronouncing, but it is also about understanding the meaning of a text.

People can understand the content of the text even the reader do not read the whole text. It happens in many languages. In comprehending English text, people can understand without understanding the whole vocabularies of the text but only some vocabularies as keyword can help the reader to comprehend the text. It needs 
knowledge from the first language and wide knowledge generally. But, we cannot say that vocabulary in English is not important.

Based on the purposes of the reading has two purposes. First, reading for pleasure. People read the material for fun, such as reading comics, novels or magazines. Second, reading for knowledge or take information of the text. People read because they need the information contained in the text, such as book, newspaper, encyclopaedia, and etc.

\section{Teaching Reading}

Teaching Reading has some method and strategies. If the method or the strategies unsuitable to the students and the material so the process of teaching reading cannot run well, sometimes the students cannot obtain the point in reading comprehension. Brown (2004, p. 229) stated that there are some strategies of reading comprehension: (1) identifying the purpose the reading, it is to make the teacher or the students finding the suitable text (2) Ensuring there are graphics and pictures to help beginners in decoding and comprehension (for beginning level learners). For intermediate to advanced levels silent reading is more efficient and suggested. The teacher should notice of each element to build up students' ability in comprehending the text.

According to Paisal Manurung (2017) the objectives of teaching English:

1) Developing communication skills in both spoken and written language.

2) Raising awareness of the nature and importance of English as a foreign language to become the main learning tool, connecting languages and cultures and enriching knowledge horizons.

There are two kinds of reading English ability; those are reading aloud and reading comprehension. In this case, HES Unhasy students need the ability to read comprehensively or to understand the contents of the text. Grab and Stoller (2011) state there are several goals for reading:

1) Reading to search for simple information and reading to skim quickly

2) Reading to learn from texts

3) Reading to integrate information, write and critique texts

4) Reading for general comprehension

Dita Yulianti (2014) added that there are two important things in reading; reading for information and reading for fun. Dita (2014) also adds that certain purposes reading has some functions to obtain simple information, to learn a text, to combine writing information and to criticize a text, and to read for general understanding. Factually, reading is the ability which enables the students directly or indirectly, reading with the purpose to find implicit message, explicit message, and general information from the text, the thoughts, facts and information that it has going to recognize the words to make a good understanding and read critically and creatively to understand kind of language.

\section{Mini Group Discussion}

Mini Group Discussion or mindis is one kind of cooperative learning which applying grouping in teaching class and every group consists of a few people about not more than 5. The researcher improved the cooperative learning generally with the name mini group discussion. There are some previus study related to the research, Nur 
Hadi Ningsih (2016) researched small group discussion in teaching reading to the junior high school, and the result showed that there are many benefits from the method. In addition, Faridatul Churiyah (2017) researched group discussion related to the understanding of students' attitude to cheat in the class. The effect of the implementation group discussion is good. Then at last, Ahadi Saputra wrote related cooperative learning in Two Stay and Two Stray in teaching reading comprehension, it is very effective implemented in the class.

\section{REASEARCH METHODS}

The rearcher used Quasi Experiment, as in Meleong (2014), the researcher took two balance classes as subject of the research. First class consists of 25 students and the other consists of 25 students, both are the students of Unhasy, on jl tromol pos no 55 Tebuireng Jombang. The researcher got the students from non english department because it has some difficulty in teaching reading English text for non-english department students.

The instruments used in the reasesarch are test and interview. The test is to measure the students enhanchement in reading English text, and the interview is to know the effect or the influence to the students' activity and process in the class. Before having treatment the resarcher got information of the students ability in reading English comprehension from pre test of both class experimental class and control class. The the researcher was conducting the threatment, after having treatment on class A, it was conducted the post test to those two classes class A and class B. There was not special threatment in class B.The test was conducted on March 2020. The interview was conducted to the students after having test. The procedure of the research are collecting the data by test and interview, then scoring the data, analyzing the data using $\mathrm{T}$ test SPSS 16, the describing the result of the interview to support the data.

These are the example of the questions in interview:

1. Do you like English?

2. If the answer is (no) Why?

3. Do you want to study/ learn English?

4. Do you like reading English in the English class?

5. If your answer (no) Why?

6. Do you think that teaching reading English in class boring?

7. Do you think the vocabularies are difficult in reading?

8. Do you think that we need to understand all vocabularies in reading?

9. Do you think that reading need another skill and knowledge?

10. Which one do you chose in teaching reading? Personal reading or collective reading?

11. How is the english methode used your lecturer in the class (MINDIS)?

12. Is it different from previous methode?

13. Do you like it?

14. What can you improve in reading English text in the class after being taught by mindis

15. Do you get any affect positive of this method?

16. What are they?

17. What do you think if this method used in another teaching or other subject or other lecturing? 


\section{DISCUSSION}

There are two problems will be discussed. Based on the first problem, the researcher is going to explain the implementation of mindis (mini group discussion) in teaching reading text in the class. There are some preparations before the treatment was conducted were preparing the material of teaching Reading, preparing the students, preparing the instruments. During in the experimental class the teacher has some steps in applying the treatments.

\section{Implementation of Mindis}

In teaching reading in the class, the researcher implemented the method (mindis) to the students. There are some steps used in the class.

1) Opening the class, conducting pre-class, introducing to the material

2) dividing the experimental class into five groups,

3) giving a text in each group,

4) asking the students scanning the text, then

5) asking some difficult vocabularies to the students and giving information to the students related to the difficult vocabularies,

6) Letting the students discuss in the group, during the students conducting the discussion, the lecturer was walking and looking around to the group while helping the group which has some questions or difficulties. Inside of the discussion, the whole students in each group must understand about everything related to the text. They can explain one another to know that they understand the text they have well. It is because every single student will explain to another group and answer some questions from another group.

7) In about 15-20 minutes, the discussion ended, then, it is time to share another group. All group shares their member to another group except one student who keep at the group waiting for another member comes to his group to share their information of the text.

8) Then it was made a new group with the different member from another group. Each member of the group shared one another, so the collecting of the different member listen and learn some information and vocabularies from another group. Every member on the group can have some questions related to the text their friends bring. Those needed about 10 minutes.

9) In the end, the member who visited another group came back to the previous group.

10) Afterward, they reconfirmed the information they get in their own group to get whole information of text, some of them shared some new vocabularies.

11) Empowering the information of the text discussed

12) Concluding to the whole class

\section{The Result of the Test}

The result of the test in applying mindis in the class of Pre-Test and post-test class B as control class and class A as the experimental class shows in Table 1. 
Table 1

\begin{tabular}{|c|c|c|c|c|c|}
\hline $\begin{array}{l}\text { Number of the } \\
\text { students Class B } \\
\text { (control class) }\end{array}$ & $\begin{array}{l}\text { Score } \\
\text { Pre-Test }\end{array}$ & $\begin{array}{l}\text { Score } \\
\text { Post-Test }\end{array}$ & $\begin{array}{l}\text { Number of the } \\
\text { students Class A } \\
\text { (experimental class) }\end{array}$ & $\begin{array}{l}\text { Score } \\
\text { Pre-Test }\end{array}$ & $\begin{array}{l}\text { Score } \\
\text { Post-Test }\end{array}$ \\
\hline 1 & 50 & 70 & 1 & 70 & 80 \\
\hline 2 & 60 & 70 & 2 & 60 & 80 \\
\hline 3 & 60 & 50 & 3 & 50 & 70 \\
\hline 4 & 65 & 65 & 4 & 65 & 70 \\
\hline 5 & 55 & 60 & 5 & 55 & 80 \\
\hline 6 & 60 & 50 & 6 & 50 & 70 \\
\hline 7 & 70 & 70 & 7 & 70 & 70 \\
\hline 8 & 60 & 70 & 8 & 60 & 80 \\
\hline 9 & 60 & 60 & 9 & 60 & 80 \\
\hline 10 & 50 & 65 & 10 & 75 & 90 \\
\hline 11 & 40 & 50 & 11 & 40 & 60 \\
\hline 12 & 70 & 0 & 12 & 75 & 80 \\
\hline 13 & 50 & 60 & 13 & 70 & 90 \\
\hline 14 & 70 & 75 & 14 & 50 & 70 \\
\hline 15 & 50 & 60 & 15 & 60 & 70 \\
\hline 16 & 60 & 65 & 16 & 50 & 80 \\
\hline 17 & 60 & 50 & 17 & 50 & 70 \\
\hline 18 & 70 & 70 & 18 & 55 & 80 \\
\hline 19 & 50 & 60 & 19 & 60 & 80 \\
\hline 20 & 55 & 60 & 20 & 55 & 60 \\
\hline 21 & 55 & 60 & 21 & 50 & 60 \\
\hline 22 & 45 & 50 & 22 & 40 & 60 \\
\hline 23 & 45 & 60 & 23 & 45 & 80 \\
\hline 24 & 50 & 60 & 24 & 60 & 70 \\
\hline 25 & 50 & 60 & 25 & 40 & 60 \\
\hline
\end{tabular}


The result of the Test (T-Test) Pre-test and Pos-test class A, Ttable= $\mathrm{t}_{(\alpha: v)}=\mathrm{t}_{(0,025 ; 24)}=2,064$.

$\mathrm{T}$ count $=10,251$. Ho is rejected and $\mathrm{H} 1$ is accepted, it means there is influence significantly before the treatment and after the treatment.

Table 3

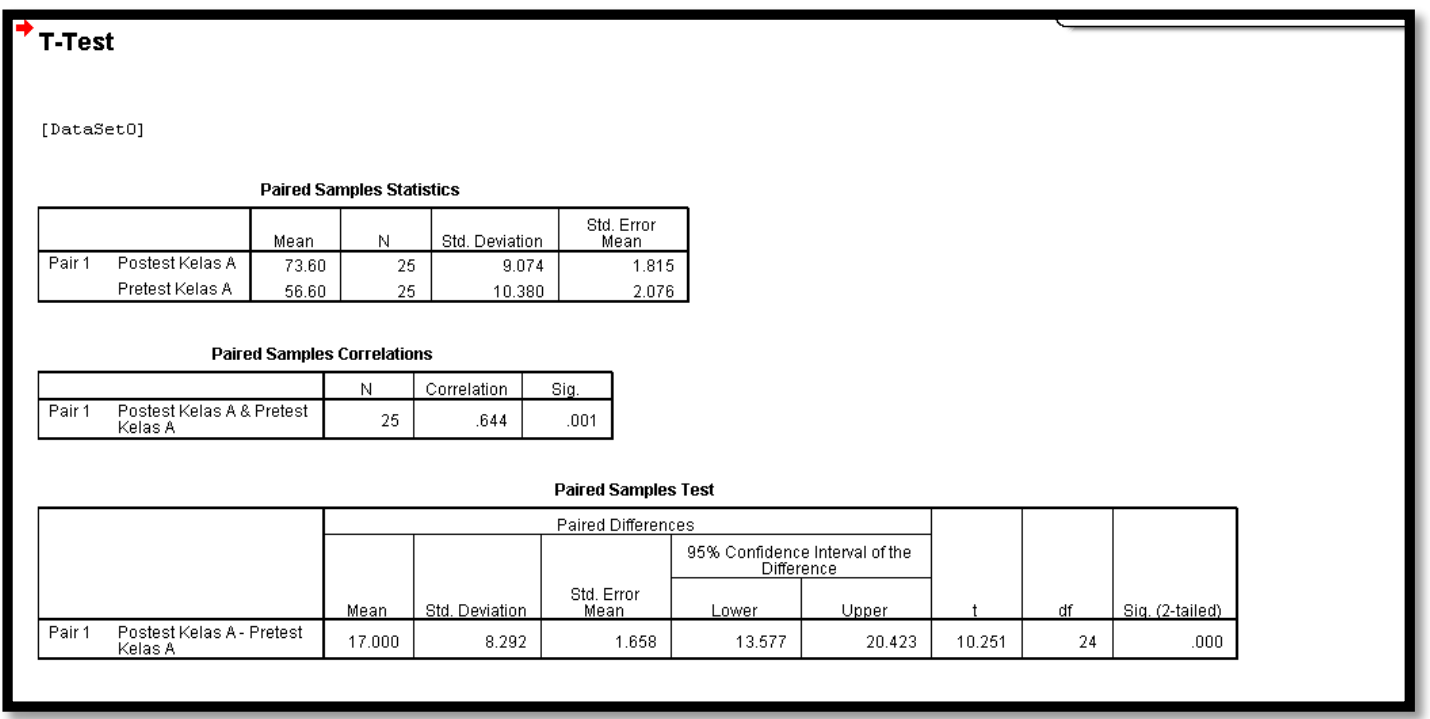

The result of T-Test to know the difference of Pre-test and Post-test class B, T table $=$ $t_{(\alpha: v)}=t_{(0,025 ; 24)}=2,064 \mathrm{~T}$ count $=0,710$. Ho is accepted and H1 is rejected it means there was no difference between pre-test and post-test of class B. It is because no special treatment into this class.

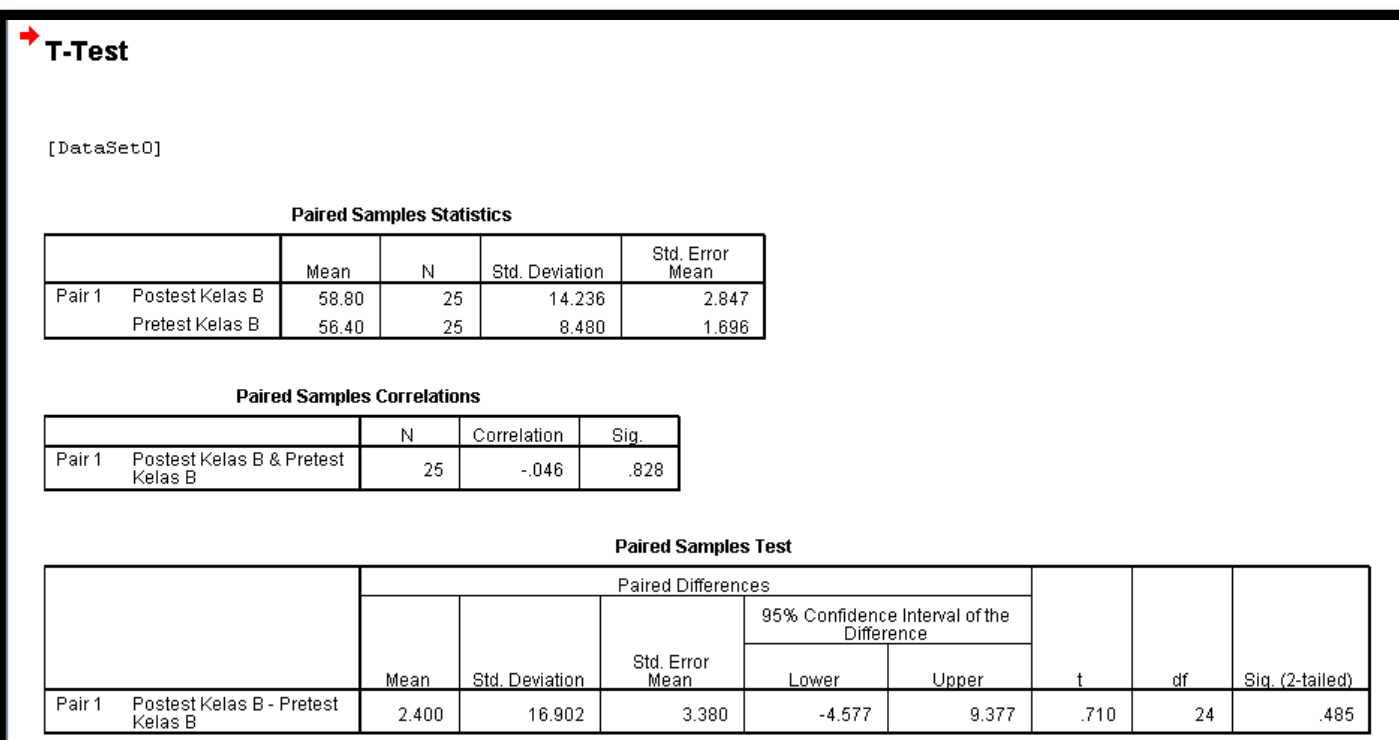




\section{The result of the interview to the students}

The interview to the student was conducted to 15 of 25 students in experimental group/class. The result shows that most of students factually wanted to learn and understand English more over when they read an English passage especially in the class, but they have some problems about lack of vocabularies and the method used in teaching English in the class. Ahmad Girsa said in his research that teaching method is important and as English teacher should know the way to deliver the material well. In addition according to Edward and Approach(Edward \& Aproach, 1963), "Method is an overall plan which have systematic step to deliver the materials consists of certain procedural of teaching".

Related to the students, when they like to learn the English but the method unsuitable, they felt bored, lazy, and difficult to understand. After being treated by using mindis, they know that teaching method influence their feel in the class, they can understand and comprehend the text better, it is one of the goal of reading Stoller (2011) stated that the students can get the goal to get the information and learn from text

While doing discussion, they can enrich some new vocabularies unconsciously. It is because automatically they listen their friends when their friends share vocabularies. Then students feel that by mindis they can ask many questions they do not understand before without feeling shy to the whole class because they ask in mini group student and the lecture often walk around to help the students. If the students should ask to the whole class, they sometimes feel shy that they do not understand the English. And the students knows that when reading English text if they have wide knowledge they can understand English text just understanding the keyword of the text or difficult vocabularies.

After being taught using mindis, the students thinks that the method may be nicer, better, and more suitable to be implemented in other subject in a term of discussion which usually one group come forward then explaining using PPT in LCD projector then the students have chance to ask. In mini group discussion, every student has a bigger chance to ask than in a big group discussion. In addition, psychologically, some students explain that, while doing discussion the students feel happy, enjoy but keep in serious during studying English in the class so it can decrease feeling bored. Other positive effect of mindis, about 10 students of 15 stated that in this discussion time make a good relationship between the lecturer and the students. The influence is very important in process of teaching and learning.

There are some positive and negative impacts of implementing this method (mindis). The following are the positive impact:

1. Enriching vocabularies unconsciously. Because they listened and knew some understanding and vocabularies many times from their friends, automatically they saved the information unconsciously in their mind. In this case, the lecturer kept guiding the students continuously and effectively. As Schulman et.al (wall,2014) said that guided reading is one of strategy in teaching reading behavior using small or mini group instruction design in discussion.

2. The teacher/ lecturer can control the students easily, because the students are in a small/mini group

3. If the groups do not change for some meeting the teacher or the lecturer can be easy to recognize the ability and the character of the students.

4. The students have chance to enrich the information of the text and exploring their understanding, because every student must be speaker, so they must 


\section{CONCLUSION}

This research is about method in Teaching Reading English passage/Text to the students of HES (Hukum Ekonomi Islam) UNHASY Tebuireng. Conducted in May 2020. And the researcher concluded that After knowing the data from the test and the interview the researcher we know that Mindis-Mini Group discussion is very useful not only in teaching reading English text, but it is probably useful also in another subject which using discussion and presentation. It is easy for the students in comprehending the passage and understanding the passage and easy for teacher in teaching and managing the class. Based on the statistics analysis, it shows that Mini Group discussion (mindis) significantly improves the students' enhancement in reading English text.

For the further researcher, this teaching method can be observed and researched in teaching another subject(material), another students, or in physiological effect accurately using certain data.

\section{REFERENCES}

Brown, H. D. (2004). Teaching by Principles. New York: Longman.Churiyah, Faridatul, Retno Tri Hastutik. 2017. SMALL GROUP DISCUSSION METHOD IN TEACHING READING COMPREHENSION IN EIGHT GRADE STUDENTS OF SMP N 3 BANTUL IN ACADEMIC YEAR 2017/2018

Creswell, John W. 2010. Research Design:Qualitative and Quantitative Approaches. California: Sage Publications, Inc McMillan J.H.

Girsa, Ahmad \& Yulianti,Dita. (2018) Effective Methode of Teaching Reading (study case).Journal Bahasa Lingua Scientia vol 10(2) 275 November 2018

Grabe, William and Fredricka L. Stoller. 2011. Teaching and Researching Reading. London: Pearson Education Limited.

Johnson, D., Johnson, R., Roseth, C., \& Shin, T. 2014. The relationship between motivation and achievement in interdependent situation. Journal of Applied Social Psychology. http://dx.doi.org/10.1111/jasp.12280

Lexy J. Moleong. 2014. Metodologi Penelitian Kualitatif. Bandung

Manurrung, Paisal, Hari Sambayu. 2017 Meningogram Studi katkan Kemampuan Bahasa Inggris Mahasiswa/I Program Studi Pendidikan Bahasa Inggris FKIPUNA dengan Literature Aproach.Prosiding Seminar NasionalMulti Disiplin Ilmu UNA.

Ningsih, Nur Hadi (2017). SMALL GROUP DISCUSSION METHOD IN TEACHING READING COMPREHENSION IN EIGHT GRADE STUDENTS OF SMP N 3 BANTUL IN ACADEMIC YEAR 2017/2018

Roseth, C., Johnson, D., \& Johnson, R. 2008. Promoting early adolescents' achievement and peer relationships: The effects of cooperative, competitive, and individualistic goal structures. Psychological Bulletin, 134, 223-246.

Saputra, Ahadi. 2016. The use of Two Stay Two Stray Strategy in Teaching Reading. Rnglish Educatin Journal 7(2), 219-232, April 2016 
Slavin, R. 2014. Cooperative learning and academic achievement: Why does groupwork work? Anales De Psicologia, 30, 785-791.

Slavin, R., Lake, C., Hanley, P. \& Thurston, A. 2014. Experimental evaluations of elementary science programs: A best-evidence synthesis. Journal of Research in Science Teaching, 51, 870-901.

Wall, H. (2014). When Guided Reading Isn't Working: Strategies for Effective Instruction. Journal of Language and Literacy Education, 10(2), 1-8. Retrieved from http://jolle.coe.uga.edu

Yulianti,Dita.(2014) Thesis: Improving the English Comprehension Ability of Grade 8 Students at SMP NEGERI 3 GEDANGSARI in the Academic Year of 2013/2014 through Extensive Reading Activities 